\title{
Relasi Hak Dan Kewajiban Suami Istri Dalam Perspektif Hukum Islam (Studi Analitis Relevansi Hak Dan Kewajiban Suami Istri Berdasarkan Tafsir Ahkam Dan Hadits Ahkam)
}

\author{
Sifa Mulya Nurani, S.Sy., M.H \\ Universitas Pelita Bangsa \\ sifamulyanurani95@pelitabangsa.ac.id
}

\begin{abstract}
A husband and wife have a significant role in carrying out all their household obligations. In addition to the obligations that must be carried out, both husband and wife also have rights attached to both, so that each is required to be able to carry out rights and obligations in a fair and balanced manner. it is necessary to clarify the meaning, intent and purpose with alHadith. With this, it will be possible to know how the relevance between the two is so that it can be a guide to realizing the goal of marriage and the formation of a happy household both physically and mentally. husband and wife in the household give rise to equal rights and obligations for both, namely the wife's right to her husband, the husband's right to his wife, and the mutual rights between the two. Second, the interpretation of the ahkam verse and its relevance to the ahkam hadith regarding the rights and obligations of husband and wife in the household can be divided into the husband's obligations which are the wife's rights and the wife's obligations which are the husband's rights. In the Qur'an it is stated that the husband must provide for his wife, treat the wife with ma'ruf (good). This right is in line with the interpretation of al-Hadith as described by Asy'ari, namely that the husband has full responsibility for the wife both regarding maintenance, treatment and other needs. Meanwhile, regarding the obligations of the wife which are the rights of the husband as stated in the Qur'an, namely that the wife must be (able) to keep everything related to her husband's property. In alHadith it is explained that this concerns everything about the wife, including the obligation to ask her husband's permission both when doing things at home (domestic work: wearing clothes, cooking and taking care of children) and when outside the home.
\end{abstract}

Keywords: Relationship, Household, Rights, Obligations, Husband, Wife

ABSTRACT: Sepasang suami istri memiliki peran yang signifikan dalam menjalankan semua kewajiban rumah tangganya. Selain kewajiban yang harus dilakukan, baik suami atau istri juga memiliki hak yang melekat pada keduanya, sehinggamasing-masing dituntut untuk bisa menjalankan hak dan kewajiban secara adil dan berkeseimbangan.Adanya ayat-yatal-Qur'an yang menjelaskan tentang hak dan kewajiban suami istri tentu perlu diperjelas makna, maksuddan tujuannya dengan al-Hadits.Dengan hal ini maka akan bisa diketahui bagaimana relevansi antara keduanya sehingga bisa menjadi pedoman untuk mewujudkan tujuan perkawinan dan terbentuknya rumah tangga yang bahagia lahir maupun batin.Artikel ini memberikan kesimpulan bahwa:Pertama,relasi antara suami dan istri di dalam rumah tangga menimbulkan hak dan kewajiban yang setara atas keduanya, yaitu hak istri atas suami, hak suami atas istri, dan hak bersama antara keduanya. Kedua, penafsiran ayat ahkam dan relevansinya terhadap hadits ahkam tentang hak dan kewajiban suami istri dalam rumah tangga dapat dibagi menjadi kewajiban suami yang menjadi hak istri dan kewajiban istri yang menjadi hak suami.Di dalam al-Qur'an disebutkan bahwa suami harus memberi nafkah istri, memperlakukan istri dengan ma'ruf(baik).Hak ini sejalan dengan tafsir al-Haditssebagaimana dipaparkan oleh Asy'ari, yaitubahwa suami mempunyai tanggung jawab penuh atas istri baik mengenai nafkah, perlakuan dan kebututuhan lainnya. Sedangkan tentang kewajiban istri yang menjadi hak suamisebagaimana disebutkan di dalam al-Qur'an yaitu bahwa istri harus (mampu) 
menjaga segala sesuatu yang berkenaan dengan milik suami. Di dalam al-Hadits diterangkan bahwa hal tersebut menyangkut segala hal tentang diri istri, di antaranya tentang kewajiban untuk meminta izin suamibaik saat melakukan hal di dalam rumah (kerja domestik: memakai pakaian, memasak dan memelihara anak) maupun saat di luar rumah.

Keywords: Hubungan, Rumah Tangga, Hak, Kewajiban, Suami, Istri

\section{PENDAHULUAN}

Perkawinan merupakan bagian dari ajaran syariat Islam yang bertujuan menjaga, memelihara dan melestarikan keturunan. Dengan perkawinan seorang laki-laki dan perempuan bisa hidup berdampingan, menjalin hubungan suami istri dan bersatu dalam sebuah ikatan keluarga secara aman. Perkawinan adalahsarana agamayang mengatur pola hubungan antara laki-laki dan perempuan untuk saling mencurahkan kasih sayang di antara mereka dan bersama-sama meraih keberkahan. ${ }^{1}$ Untuk itu, sebagai ibadah luhur yang (dianggap) sakral, perkawinan harus dilakukan atas dasar keikhlasan, penuh tanggung jawab dan sesuai dengan ketentuan hukum yang ada. ${ }^{2}$

Agama Islam mengajarkan bahwa setiap perbuatan harus dilakukan semata-mata karena mengharap ridho dari Allah SWT.Artinya, seseorang yang telah menikah berarti juga memasuki dunia dan kehidupan yang baru pula.Sehingga harus bisa memadukan antara urusan duniawi dengan urusan ukhrawiyang berdimensi insani dengan yang profan ${ }^{3}$ secara arif dan bijaksana. ${ }^{4}$ Kehidupan dalam bingkai perkawinan harus dijalani dengan penuh kesadaran, rasa kasih sayang, saling hormat-menghormati, mampu menjaga rahasia dan aib masing-masing dan bisa saling melengkapi antara satu dengan yang lain. Antara suami istri harus bisa saling memahami dan menjaga hak dan kewajibannya masing-masing secara adil dan seimbang sesuai dengan Q.S. al-Baqarah ayat 228 yang berbunyi:

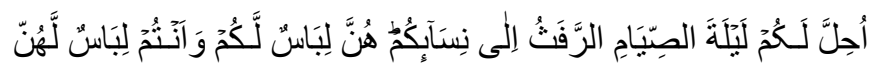

Artinya:Dihalalkan bagimu pada malam hari puasa bercampur dengan istrimu. Mereka adalah pakaian bagimu, dan kamu adalah pakaian bagi mereka. ${ }^{5}$

Dari ayat tersebut jelas bahwa pola hubungan yang dikehendaki adalah hubungan saling membutuhkan antara satu pihak (suami) dengan pihak lainnya (istri). Antara suami dan istri memiliki hak dan kewajiban masing-masing yang harus dihormati dan dijaga dengan sepenuh hati demi terwujudnya cita-cita perkawinan, yaitu kehidupan

${ }^{1}$ Siti Musdah Mulia, Membangun Surga Di Bumi; Kiat-Kiat Membina Keluarga Ideal Dalam Islam (Jakarta: PT Garamedia, 2011), 40.

2 Wibisana, Wahyu. Perkawinan Dalam Islam. Jurnal Pendidikan Agama Islam -Ta'lim Vol. 14, No. 2. 2016.

3 Profan adalah tidak bersangkutan dengan agama atau tujuan ke agamaan, Lihat pada https:// kbbi.web.id/profan. Diakses pada tanggal 13 Oktober 2020 pukul 15.00 WIB.

${ }^{4}$ La Jamaa "Advokasi Hak-Hak Istri Dalam Rumah Tangga Perspektif Hukum Islam" (Jurnal, Fakultas Syariah dan Ekonomi Islam IAIN Ambon, 2016).

${ }^{5}$ Kementrian Agama RI, Al-Qur'an dan Tafsirnya:Edisi yang Disempurnaka ( Jakarta: Widya Cahaya, 2011) 
bersama (suami istri) yang sakinah, mawaddahwa rahmah (penuh ketenangan dan kasih sayang) baik di dunia maupun nanti di akhirat.

Sebagai agama yang kaffah, Islam juga memberikan arahan tentang tata kehidupan suami istri baik itu melalui ayat-ayat al-Qur'an maupun yang dijelaskan melalui alHadits, karena tidak semua ayat-ayat dalam al-Qur'an tersebut bisa langsung dipahami secara tekstual.Di sinilah peran, fungsi dan kewenangan Nabi SAW. ${ }^{6}$ sebagai pihak yang menerima wahyu al-Qur'an untuk memberikan penafsiran dan penjelasan sehingga ayat-ayat tersebut bisa dipahami maknanya secara jelas dan tegas. ${ }^{7}$

Berpijak pada hal-hal tersebut di atas, antara suami dan istri adalah mitra yang saling berhubungan secara erat tanpa subordinisi baik dalam pemenuhan hak maupun kewajiban yang diatur dalam al-Quran dan al-Hadits. Dalam konteks inilah tulisan ini akan memaparkan bagaimana relevansi ayat-ayat al-Qur'an tentang hak dan kewajiban suami istri dengan al-Hadits yang mengemukakan tentang hal yang sama. Dengan uraian ini diharapkan bisa diketemukan sebuah formulasi ideal tentang hubungan suami istri dalam bingkai ajaran agama Islam.

\section{HAK DAN KEWAJIBAN SUAMI ISTRI}

\section{Pengaturan Hak dan Kewajiban Suami Istri Dalam Undang-Undang}

Dalam kontek Indonesia, suatu perkawinan dianggap sah apabila telah memenuhi ketentuan yang diatur dalam Undang-Undang No. 1 tahun 1974 tentang Perkawinan (UUP 1974) dan aturan pelaksaksanaannya yang tertuang dalam Peraturan Pemerintah No. 9 tahun 1975 (PP 9 tahun 1975). Dengan demikian maka segala konsekuensi hukum yang terjadiakibat perkawinan (hubungan suami istri) baik itu yang menyangkut soal hak dan (juga) kewajiban berlaku efektif setelah dipenuhinya unsur-unsur yang diatur dalam peraturan perundang-undangan tersebut.

Hal tersebut di atas, sesuai dengan apa yang dijelaskan dalam pasal 2 dari UUP 1974 dan dipertegas dalam Penjelasan Umum nomer 4 yang menerangkan tentang keabsahan perkawinan, yaitu: pertama, perkawinan (dianggap) sah apabila dilakukan sesuai dengan ketentuan peraturan (hukum) agama dan atau kepercayaannya; kedua, perkawinan sebagaimana tersebut harus dan telah dicatatkan sebagaimana ketentuan perundang-undangan yang berlaku.

Dengan ketentuan tersebut maka segala bentuk perkawinan yang dilakukan tanpa adanya 2 prinsip (azas) keabsahan sebagaimana tersebut, dianggap tidak sah

${ }^{6}$ Hairul Hudaya "Hadits-Hadits Tentang Penafsiran Hak dan Kewajiban Suami Istri dalam Tafsir At-Tabhari (Studi Kualitas dan Relevansi Kandungannya) Disertasi: UIN Sultan Alaudin Makasar. 2013.

7 Penafsiran adalah proses sulit yang tidak bisa dilakukan oleh sembarang orang. Buya Hamka dalam Tafsir al-Azhar, melakukan penafsiran secara bertahab yaitu dengan lebih dahulu melihat ayat per ayat, kemudian menyambungkannya dengan ayat-ayat lain yang sejenis. Semua proses penafsiran ini harus didasarkan pada al-sunnah, yaitu perkataan dan perilaku Nabi serta yang dilakukan oleh sahabat beliau yang disetujuhi. Hal ini mutlak harus dilakukan karena dalam menafsikran al-Quran tidak boleh bertentangan dengan apa yang ada dalam al-Sunnah.Lihat pada https://id.wikipedia.org/wiki/Tafsir.Diakses pada tanggal 14 Oktober 2020 pukul 14.00 WIB. 
secara hukum . Hal ini sesuai dengan apa yang ditegaskan dalam Penjelasan pasal 2 ayat (1) dari UUP 1974 yang menyatakan bahwa tidak ada perkawinan di luar hukum agama dan kepercyaan sesuai yang diatur dalam UUD 1945. Artinya, perkawinan harus terjadi sesuai dengan ketentuan agama atau kepercayaan yang diyakini orang tersebut, sepanjang tidak bertentangan dengan peraturan perundangundangan yang berlaku atau karena hal lain yang (telah) ditetapkan oleh undangundang.

Terkait hal tersebut di atas, Hazairin menyatakan bahwa tidak ada kemungkinan bagi orang Islam untuk melanggar aturan (hukum ) agamanya. Demikian juga halnya dengan umat beragama lain seperti Kristen, Hindu, Budha dan lain sebagainya. ${ }^{8}$ Sehingga dalam konteks perkawinan, mereka semua (masingmasing umat beragama) juga akan patuh dan tunduk pada ajaran agama atau kepercayaannya masing-masing. Inilah ruh sesungguhnya dari prinsip keabsahan perkawinan yang tertuang dalam UUP tahun 1974, yaitu bahwa sah tidaknya perkawinan diukur dengan: pertama, apakah perkawinan tersebut (telah) dilakukan sesuai dengan ketentuan hukum agama dan atau kepercayaannya masing-masing atau tidak; kedua, apakah perkawinan tersebut juga telah dicatatkan sesuai dengan ketentuan perundang-undangan yang berlaku. ${ }^{9}$

Sehingga berdasar pada ketentuan yang ada di dalam UUP 1974 tersebut bisa diambil kesimpulan tentang dominannya unsur agama dalam masalah perkawinan di Indonesia. Adanya ketentuan tentang keabsahan perkawinan (harus) berdasar pada ketentuan hukum agama dan kepercayaan masing-masing, menunjukkan unifikasi UUP 1974 sebagai perundang-undangan negara yang ditetapkan sebagai pedoman perkawinan . ${ }^{10} \mathrm{Di}$ satu sisi pengaturan tersebut menunjukkan sisi religiusitas yang kental sebagai ruh atau jiwa undang-undang tersebut dan di sisi lain dala wujud material undang-undang merupakan apresiasi terhadap keragaman yang ada di Indonesia. Pada prakteknya, konsekuensi dari undang-undang ini adalah bahwa perkawinan harus memenuhi 2 unsur hukum sekaligus yaitu hukum agama dan hukum Negara. ${ }^{11}$

Ketentuan tentang keharusan pelaksanaan pencatatan perkawinan sebagaimana dalam UUP 1974 tersebut, ditegaskan dalam Kompilasi Hukum Islam (KHI) sebagaimana berikut:

8 Hazairin, Undang-Undang Perkawinan No. 1 tahun 1974 (Jakarta: Tintamas,1975), 5-6.

${ }^{9}$ Dalam Penjelasan Umum UUP 1974 pada Sub (4b), disebutkan bahwa pencatatan perkawinan sama halnya dengan pencatatan pada peristiwa-peristiwa penting dalam kehidupan seseorang, misalnya pada kelahiran, kematian dan lain sebgainya yang dinyatakan dalam bentuk surat keterangan atau akta yang dimuat dalam daftar pencatatan resmi Negara.

${ }_{10}$ Moch. Isnaeni, Hukum Perkawinan Indonesia (Bandung: PT Refika Aditama,2016), 38.

11 Dalam ranah praktis, dengan hanya menjalankan salah satu ketentuan hukum yang barlaku maka perkawinan tersebut dianggap tidak legal. Hal ini seperti jika seseorang melakukan proses perkawinan dengan ketentuan agama saja maka perkawinan nya tidak sah menurut hukum Negara, sehingga seringkali perkawinan ini disebut sebagai perkawinan diam-diam (sirri) karena tidak adanya keterlibatan Negara di dalam proses terjadinya. 
a. Pasal 5 ayat (1) dalam KHI dinyatakan bahwa untuk menjamin ketertiban masyarakat Islam dalam masalah perkawinan, maka setiap perkawinan harus dicatatkan;

b. Pencatatan perkawinan sebagaimana dimaksud adalah bahwa setiap perkawinan harus dilaksanakan di hadapan dan dalam pengawasan Pegawai Pencatat Nikah (pasal 6 ayat 1 dari KHI);

c. Dengan demikian maka perkawinan yang dilakukan tanpa kehadiran dan pengawasan Pegawai Pencatat Perkawinan yang telah ditentukan, tidak mempunyai kekuatan hukum (KHI pasal 6 ayat 2 )

Mencermati ketentuan-ketentuan hukum yang terdapat dalam peraturan perundang-undangan tentang perkawinan sebagaimana uraian tersebut di atas, tampak nyata adanya kehendak (kuat) untuk memadukan unsur-unsur agama dengan sistem administrasi Negara. Menurut D.Y Witanto, perpaduan yang dirumuskan dalam pasal-pasal perundang-undangan perkawinan sebagaimana tersebut memiliki 2 konsekuensi logis, yaitu positif dan negatif: 12

\section{a. Positif}

Dengan adanya ketentuan tersebut akan menjadikan perkawinan (tetap) sebagai bagian dari proses pemenuhan kewajiban menjalankan ajaran agama bagi masing-masing penganutnya dan di satu sisi Negara memiliki kesempatan (hak) untuk mengaturnya dalam bingkai kepentingan kebangsaan.

b. Negatif

Pengaturan Negara atas perkawinan juga bisa dipandang sebagai bentuk intervensi Negara terhadap persoalan keagamaan.Karena perkawinan diyakini sebagai bentuk ajaran agama yang bernilai ibadah, sehingga tidak ada hubungannya dengan Negara.

Terlepas adanya konsekuensi positi dan negative tersebut, hadirnya Negara dalam konteks perkawinan harus (bisa) dipahami sebagai wujud pemberian perlindungan (hukum ) Negara terhadap warganya. Artinya, dengan adanya pencatatan secara admistrasi terhadap suatu perkawinan, maka akan memberi konsekuensi sebab akibat (hukum ) yang timbul dari perkawinan tersebut. Otentikasi perkawinan akan memberikan manfaat hukum seperti misalnya adanya kejelasan status kelahiran (anak) dan jaminan atas kemungkinan adanya tuntutan hukum dari pihak lain atas perkawinan yang dilakukan.

Dengan demikian, hakikat perkawinan sebagaimana dikehendaki UUP 1974 yang menegaskan keabsahan perkawinan baik dari sisi agama dan Negara harus dipahami sebagai bentuk ihtiyar (usaha) untuk mencapai ke-meslahatan(kemanfaatan) yang lebih luas. Sehingga perkawinan yang dilakukan hanya berdasar pada ketentuan agama saja tanpa adanya proses pencatatan sebagaimana ketentuan undang-undang dianggap tidak sah secara hukum Negara dan tidak akan

12 D.Y. Witanto, Hukum Keluarga : Hak dan kedudukan anak luar kawin (Jakarta: Prestasi Pustaka, 2012), 132-133. 
mendapatkan hak-hak hukum sebagaimana telah dijelaskan. Inilah penjelasan sederhana dari pentingnya melaksanakan pengadministrasian dalam perkawinan.

Secara lebih khusus, hak-hak hukum yang terjadi sebagai akibat dari perkawinan yang dilaksanakan secara sah bisa dijelaskan dengan mengambil contoh tentang perkawinan di bawah umur di mana sesuai dengan ketentuan adalah 21 tahun untuk laki-laki dan 18 tahun bagi perempuan. Seorang laki-laki dan perempuan yang belum memenuhi ketentuan batasan umur dianggap sebagai orang yang tidak cakap melakukan perbuatan hukum (onbekwaam). Namun demikian ketidakcakapan ini akan serta merta hilang dan dianggap cakap (bekwaan) pasca terjadinya perkawinan. Artinya, setelah proses perkawinan terjadi secara otomatis juga melekat (secara hukum) hak dan kewajibannya sebagai suami istri.

Di antara hak dan kewajiban sebagai suami istri tersebut diatur dalam Kitab Undang-Undang Hukum Perdata (KUH Perdata) pasal 103-107 yang menyebutkan bahwa antara suami dan istri harus saling setia, tolong-menolong dan bantumembantu.Keduanya merupakan satu kesatuan yang berkewajiban untuk saling memelihara, menjaga danmendidik anak-anak mereka.Suami berperan sebagai kepala perkawinan (rumah tangga) yang harus memimpin dengan baik sehingga sebagai istri wajib patuh dan mengikutinya.Seorang istri wajib tinggal bersama dengan suaminya dan sebaliknya suami wajib menerima dan memperlakukan istrinya dengan baik.Suami wajib memberikan perlindungan, rasa aman dan memenuhi kebutuhan istrinya sesuai kedudukan dan kemampuannya.

Terkait bagaimana kedudukan hokum yang menimbulkan hak dan kewajiban suami istri setelah terjadinya perkawinan yang sah, Surat Edaran Mahkamah Agung No. 3 tahun 1963, terdapat perbedaan antara apa yang ada di UUP 1974 dengan KUH Perdata. Menurut KUH Perdata pasal 108, seorang perempuan yang terikat tali perkawinan pada prinsipnya menjadi tidak cakap melakukan perbuatan hokum. Sementara dalam UUP pasal 31, perempuan tersebut dianggap tetap cakap melakukan perbuatan hokum.Perbedaan kedudukan (hokum) tentang perempuan sebagaimana hal tersebut menjadi penting untuk ditelusuri karena memiliki konsekuensi logis (hokum) yang melekat.

Menurut UUP, suami istri harus mempunyai rumah sebagai tempat tinggal tetap yang ditentukan secara bersama-sama antara suami dan istri (pasal 32) sehingga kehidupan rumah tangga yang dibangun antara suami istri tersebut didasari oleh perasaan saling cinta mencintai, hormat menghormati, setia menyetiani dan saling bantu antara satu dengan yang lain (pasal 33). Demikian juga dalam menentukan penggunaan terhadap harta bersama juga dilakukan atas persetujuan kedua belah pihak.Semetara terhadap harta bawaan masing-masing maka suami atau istri tersebut memiliki hak sepenuhnya untuk menggunakannya (pasal 36, nomor 1 dan 1).

Ketentuan-ketentuan tersebut berbeda dengan apa yang ada pada KUH Perdata. Dalam pasal 124 disebutkan bahwa yang berwenang untuk mengurus harta kekayaan perkawinan adalah suami, baik itu untuk menjual, memindah tangankan 
ataupun menggadaikannya tanpa adanya ketentuan untuk melibatkan campur tangan dari pihak istri.

Pada sisi yang lain, karena kodrat anatar keduanya (laki-laki dan perempuan), berdasar peran dan posisinya dalam perkawinan, hukum juga membedakan status antara suami dengan istri. Berdasar pada Pasal 105 ayat 1 dalam KUH.Perdata suami adalah kepala perkawinan dan dalam Pasal 31 ayat 3 UUP, suamiadalah sebagai kepala rumah tangga dan istri adalah ibu rumah tangga. Dengan status inilah suami berkewajiban untuk melindungi istrinya dan juga memberikan segala keperluan hidup dalam berumah tangga sesuai dengan kemampuannya. Sedangkan bagi istri, berdasar pada Pasal 107 KUH.Perdata dan Pasal 34UUP, memiliki kewajibandalam mengatur urusan rumah tanggadengan sebaik-baiknya..

Selain berdampak (hokum) pada adanya hak dan kewajiban, ikatan perkawinan antara suami istri juga membawa akibat timbulnya hubungan semenda antara mereka dengan keluarga pasangannya yaitu: pertama,antara suami dengan orang tua pihak istri terjalin hubungan menantu dengan mertua; kedua,suamidengan keluarga pihak istri terjalin hubungan periparan (saudara ipar). Adanya hubungan semenda ini (juga) menimbulkan konsekuensi hukuam, seperti misalnya misalnya antara menantu dengan mertua dilarang melangsungkan perkawinan.

Sebagai akibat adanya perkawinan, juga menimbulkan hubungan alimentasi, yaitutimbulnya hak dan kewajiban timbal balik antara orang tua dan anak. Artinya, apa yang menjadi kewajiban orang tua terhadap anak adalah hak anak, demikian pula apa yang menjadi kewajiban anak kepada orang tua adalah hak orang tua. Dalam pasal 298 jo 321 KUHPerdata disebutkan bahwaorang tua memiliki kewajiban untuk memelihara dan mendidik anak-anaknya, anak harus hormat dan patuh pada orang tua dan apabila sudah dewasa (mampu) wajib memberi nafkah kepada orang tua. Hal ini sesuai dengan padal 45-48 dari UUP yang juga menyebutkan tentang hak dan kewajiban antara orang tua dan anak.

Lebih jauh tentang hak dan kewajiban anatar suami istri juga diatur dalam Kompilasi Hukum Islam (KHI) pasal 77-84 yang memiliki kesenadaan dengan apa yang telah dicantumkan dan diatur dalam diatur dalam UUP.Dari uraian dan penjelasan tentang hak dan kewajiban suami istri ini, baik itu yang ada di dalam UUP, KUH Perdata dan KHI terlihat bahwa ketentuan-ketentuan yang terdapat di dalam UUP memberi suami istri kedudukan yang seimbang di dalam perkawinan. Hal ini merupakan perwujudan, pemenuhan dan pencerminan darisalah satu asas perkawinan yang menyatakan bahwa hak dan kedudukan istri adalah seimbang dengan hak dan kedudukan suami baik dalam kehidupan rumah tangga maupun dalam pergaulan masyarakat.

\section{Konsep Relasi Suami Istri dalam Perkawinan Islam}

Perkawinan adalah merupakan cara (aturan hukum ) yang mengatur manusia untuk terhindar dari perbuatan zina yang diharamkan agama. Dengan perkawinan hubungan badaniyah antara seorang laki-laki dan perempuan menjadi boleh (halal) dilakukan. Dalam ajaran syariat Islam, perkawinan dilakukan sekali seumur hidup 
untuk membina kasih sayang dan mewujudkan kehidupan keluarga yang sakinah, mawaddah wa rahmah sebagaimana yang terkandung dalam Q.S. al-Rum ayat 21 sebagaimana berikut:

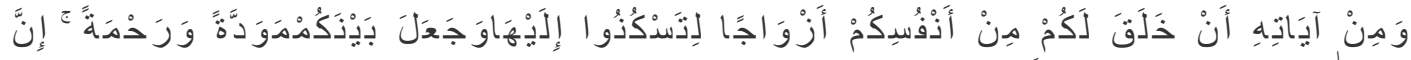

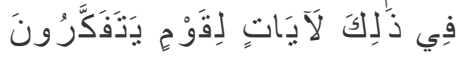

Artinya:Dan di antara tanda-tanda kekuasaan-Nya ialah Dia menciptakan untukmu istri-istri dari jenismu sendiri, supaya kamu cenderung dan merasa tenteram kepadanya, dan dijadikan-Nya di antaramu rasa kasih dan sayang. Sesungguhnya pada yang demikian itu benar-benar terdapat tanda-tanda bagi kaum yang berfikir. ${ }^{13}$

Untuk mewujudkan kehidupan suami istri sebagaimana yang disebutkan dalam ayat tersebut, maka baik itu suami ataupun istri harus bisa memerankan fungsi dan tugas masing-masing dengan penuh rasa tanggung jawab. Antara suami istri harus bisa saling bekerja sama secara kompak dan berkesinambungan, saling pengertian antara satu dengan yang lain dan bisa menjaga keseimbangan antara hak dan kewajiban sehingga akan tercipta suasana rumah tangga yang aman, damai dan sejahtera. Pada gilirannya jika hal-hal tersebut bisa dijaga dan dilestarikan maka kehidupan rumah tangga menjadi harmonis dan kebahagiaan keluarga bisa diraih.

Dalam Islam, konsep relasi suami istri sebagaimana di atas merupakan salah satu aspek yang telah diatur sedemikian rupa agar suami maupun istri bisa menunaikan hak dan kewajibannya masing-masing untuk membina keluarga yang bahagia lahir dan batin sesuai syariat Islam. Dengan demikian kehadiran hukum keluarga islam harus difungsikan sebagai pedoman dan sekaligus panduan untuk mengatur pola hubungan antar segenap anggota keluarga. ${ }^{14}$ Artinya baik suami, istri, anak dan seluruh anggota keluarga lainnya harus patuh, tunduk dan menjadikan hukum tersebut sebagai panduan keseharian secara bertanggung jawab demi tercapainya tujuan perkawinan. ${ }^{15}$

Kebahagiaan lahir dan batin sebagai tujuan akhir pernikahan yang termanifestasi dalam kehidupan keluarga yang sakinah, mawaddah wa rahmah harus dipahami sebagai serangkaian proses menggapai ridho Allah SWT. Untuk itu segala macam perasaan cinta, kasih dan sayang yang tercermin dalam sikap dan perbuatan harus dilandasi kesungguhan (keyakinan) untuk mendatangkan kebaikan dan menolak segala hal yang merusak dan berpotensi menggagunya. ${ }^{16}$

13 Kementrian Agama RI, Al-Qur'an dan Tafsirnya:Edisi yang Disempurnakan (Jakarta: Widya Cahaya, 2011).

${ }^{14}$ Muhammad Amin Summa, Hukum Keluarga Islam di Dunia Islam (Jakarta: PT. Raja Grafindo Persada, 2005), 31.

15 Umar Haris Sanjaya dan Aunur Rahim Faqih, Hukum Perkawinan Islam di Indonesia (Yogyakarta: Gama Media, 2017), 76.

${ }_{16}$ M. Quraish Shihab, Untaian Permata Buat Anakku: Pesan Al-Qur'an untuk Mempelai (Bandung: Al-Bayan, 1998), 47. 
Hubungan dalam keluarga bukanlah seperti hubungan antara majikan dan bawahan. ${ }^{17}$ Tetapi merupakan hubungan yang mengedepankan keadilan dalam peran dan fungsi dan keseimbangan dalam memposisikan soal hak dan kewajiban.Untuk itu dalam rangka menggapai hakikat perkawinan harus ada kerja sama yang baik, saling pengertian dan memahami antara satu dengan yang lain. Peran harus bisa difungsikan secara adil dan bijaksana dan sebaliknya terhadap fungsi masingmasing harus bisa diperankan secara seimbang.Inilah konsep relasi hubungan suami istri dalam keluarga yang diharapkan sehingga tercapai kehidupan rumah tangga yang berbahagia lahir maupun batin.

\section{Hak dan Kewajiban Suami Istri}

Disebutkan dalam Kamus Besar Bahasa Indonesia (KBBI) bahwa hak memiliki arti sebagai milik dan kepunyaan.Sedangkan kewajiban memiliki arti sebagai sesuatu yang harus dilaksanakan. ${ }^{18}$ Dari pengertian tersebut bisa disimpulkan bahwa yang dimaksud dengan hak adalah segala sesuatu yang (telah) diterima dari orang lain. Adapun yang dimaksud dengan kewajiban adalah segala sesuatu yang harus dilakukan seseorang terhadap yang lain. ${ }^{9}$ Sehingga dalam konteks hubungan suami istri, hak dan kewajiban bisa dimaknai sebagai segala sesuatu yang harus diterima dan (sekaligus) dilakukan sebagai konsekuensi dari adanya hubungan perkawinan.

Selanjutnya, hak dan kewajiban yang melekat pada masing-masing pihak baik suami maupun istri merupakan konstruksi peran dan fungsi dari kedua belah pihak yang melekat dan mesti diterima dan dimiliki.Artinya, hak adalah sesuatu yang melekat dan mesti didapatkan sedangkan kewajiban merupakan sesuatu yang harus diberikan dan dilakukan.Rumusan tentang hak dan kewajiban inilah yang kemudian menjadi barometer (standart) untuk menilai apakah suami atau istri telah menjalankan peran dan fungsinya secara benar atau tidak. ${ }^{20}$

Lebih jelasnya, dalam suatu hubungan rumah tangga baik suami maupun istri memiliki hak dan kewajibannya masing-masing. Di satu sisi istri memiliki hak atas nafkah dan pada sisi yang lain mempunyai kewajiban untuk taat. Pada titik inilah konsekuensi hukum sebab akibat hubungan perkawinan menjadi muncul dan mengemuka.Hal ini seperti misalnya jika suami tidak mampu memenuhi kewajibannya dalam memberi nafkah istri, maka gugurlah haknya untuk mendapat ketaatan dari istri. ${ }^{21}$

${ }_{17}$ M. Quraish Shihab, Pengantin Al-Qur'an: Kalung Permata buat Anak-Anakku (Jakarta: LLentera Hati, 2007), 11.

18 Depaertemen Pendidikan Nasional, Kamus Besar Bahasa Indonesia (Jakarta:Balai Pustaka 2001), 1266.

${ }^{19}$ Amir syarifuddin, Hukum Perekonomian Islam di Indonesia (Jakarta:Prenada Media, 2006),159.

${ }^{20}$ Hamim Ilyas, Perempuan Tertindas; Kajian Haditshadits Misoginis(Yogakarta: EQsaq Pres, Pusat Studi Wanita, UIN Sunankalijaga, 2005), 122.

21 Marhumah, "Perempuan Indonesia dalam Memahami hak dan Kewaiban Dalam Keluarga"(Jurnal Musawa: Studi Gender dan Islam 2014), 157. 
Tentang keseimbangan hak dan kewajiban antara suami dan istri dalam kehidupan berumah tangga dijelaskan al-Qur'an surat al-Baqarah ayat 228 sebagaimana berikut:

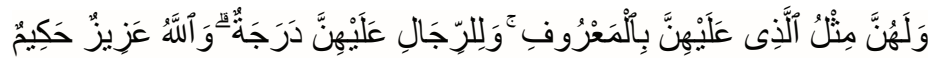

Artinya:Dan Para wanita mempunyai hak yang seimbang dengan kewajibannya menurut cara yang ma'ruf. Akan tetapi para suami mempunyai satu tingkat kelebihan dari pada istrinya.Dan Allah Maha Perkasa lagi Maha Bijaksana. ${ }^{22}$

Berdasar pada keterangan ayat tersebut di atas, istri dan juga suami mempunyai hak yang setara dan seimbang dengan kewajibannya sesuai peran dan posisinya masing-masing.Seorang istri wajib menunaikan segala kewajibannya kepada suami dan begitu pula suami harus juga bisa melaksanakan kewajibannya kepada istrinya. Dengan keseimbangan yang terjadi dan dilakukan sebagai kewajiban masing-masing secara bertanggung jawab maka hak dari masing-masing akan bisa diwujudkan secara adil pula. Dan jika yang terjadi sebaliknya atau salah satu di antara keduanya lalai dan tidak bertanggung jawab bisa dipastikan kehidupan keluarga akan mengalami kerenggangan dan keretakan.

Adapun terhadap keterangan dalam Q.S al-Baqarah ayat 228 yang menyatakan bahwa laki-laki mempunyai satu tingkat kelebihan dari istri harus dipahami secara bijaksana.Berdasar pada pegertian-pengertian yang (telah) dilakukan oleh para mufassir, ayat ini berhubungan erat dalam permasalahan talak (perceraian). ${ }^{23}$ Sehingga argumentasi tentang derajat (tingkat) laki-laki lebih tinggi dari perempuan tidak bisa begitu saja bisa diterapkan dalam konteks hubungan keluarga antara suami dan istri, utamanya yang berketerkaitan tentang hak dan kewajiban dalam bingkai kehidupan rumah tangga.

Artinya, hak dan kewajiban antara suami dan istri harus bisa diterapkan secara bijaksana dengn mempertimbangkan berbagai aspek baik secara fisik maupun mental sehingga peran dan fungsi masing-masing bisa dilaksanakan secara maksimal dan berkesesuain.Di antara pertimbangan dalam peran tersebut adalah adanya pembagian bahwa istri (karena tidak bekerja yang mendatangkan penghasilan) mempunyai kewajiban mengurus urusan dalam keluarga seperti memelihara dan mendidik anak, mengurus rumah tangga dan lain sebagainya.Sementara suami memiliki tugas dan kewajiban untuk mencari penghasilan (nafkah) yang cukup untuk memenuhi kebutuan keluarga.

Namun demikian hal-hal sebagaimana tersebut hanyalah contoh pembagian peran dan tanggung jawab yang tidak baku. Dalam kondisi tertentu seorang istri juga bisa mengambil peran sebaliknya dengan tujuan membantu (tabarru'), bukan sebagai kewajiban mutlak. ${ }^{24} \mathrm{Hal}$ ini terjadi misalnya jika suami benar-benar dalam kondisi

22 Kementrian Agama RI, Al-Qur'an dan Tafsirnya:Edisi yang Disempurnakan (Jakarta: Widya Cahaya, 2011).

23 Ibid.

${ }^{24}$ Ibid., 338. 
yang tidak (belum) memungkinkan untuk melaksanakan kewajibannya secara penuh karena adanya halangan yang bersifat syar'i, seperti sakit atau masalah lainnya.Tetapi jika kondisi telah normal kembali, maka kewajiban memberi nafkah tetap kembali melekat sebagai tanggung jawab (kewajiban) suami dan menjadi hak yang dimiliki oleh istri. ${ }^{25}$ Dengan ini, apapun alasannya mencari dan memberi nafkaf merupakan kewajiban seorang suami.

Secara lebih detail, hak dan kewajiban antara laki-laki dan perempuan yang timbul akibat perkawinan harus disesuaikan dengan penilaian dan pandangan (social budaya) masyarakat serta berlakunya azas kebermanfaatan menurut ajaran syariat. ${ }^{26}$ Hak dan kewajiban suami istri sebagaimana tersebutbisa dirangkum dalam 3 macam hak yang menjadi kewajiban masing-masing pihak (suami istri) untuk mewujudkan kebahagiaan keluarga, yaitu: pertama, hak istri atas suami; kedua, hak suami atas istri dan yang ketiga, hak bersama antara suami dan istri. ${ }^{27}$

\section{a. Hak Istri atas Suami}

Sebagaimana telah dijelaskan bahwa perkawinan merupakan sarana agama untuk menghalalkan hubungan badan antara laki-laki dan perempuan sehingga, sehingga tidak terjerumus dalam perzinaan. Dalam proses pelegalan hubungan badaniyah (perkawinan yang sah) inilah kemudian muncul hak dan kewajiban bagi seorang perempuan (istri) yang dirumuskan dalam bagan sederhana sebagaimana berikut, yaitu: 28

\begin{tabular}{|l|l|}
\hline \multicolumn{1}{|c|}{ Hak } & \multicolumn{1}{c|}{ Kewajiban } \\
\hline Hak mendapatkan mahar & $\begin{array}{l}\text { Taat dan patuh kepada } \\
\text { suami }\end{array}$ \\
\hline $\begin{array}{l}\text { Hak mendapatkan perlakuan } \\
\text { yang ma'ruf dari suami. }\end{array}$ & $\begin{array}{l}\text { Mengatur rumah dengan } \\
\text { sebaik-baiknya }\end{array}$ \\
\hline $\begin{array}{l}\text { Dijaga nama baik oleh si } \\
\text { suami, danlain-lain. }\end{array}$ & $\begin{array}{l}\text { Menghormatikeluarga suami } \\
\text { danlain-lain }\end{array}$ \\
\hline Hak mendapatkan nafkah & $\begin{array}{l}\text { Menghormatikeluarga suami } \\
\text { danlain-lain }\end{array}$ \\
\hline
\end{tabular}

25 Hamim Ilyas, 122.

26 Syaikh Muhammad Nawawi bin Umar al-Jawi, Keluarga Sakinah, terj.Ali Chasan Umar (Semarang: Karya Toha Putra,1994), 13.

27 Sayyid Sabiq, Fiqih Sunah Jilid 3: Pengantar Imam Hasan Al-Bana (Surakarta Insan Kamil, 2016), 39.

${ }^{28}$ Muhammad Nasib Ar-Rifa'i, Kemudahan dari Allah: Ringkasan Tafsir Ibnu Katsir Jilid 2 (Jakarta: Gema Insani, 1999), 39. 
Seorang perempuan yang disahkan sebagai istri berhak untuk mendapatkan mahar dari suami dan suami wajib memberikannya untuk istrinya. Hal ini sesuai dengan Q.S. al-Nisa' ayat 4 yang berbunyi:

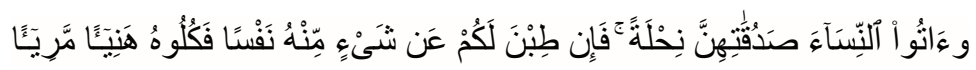

Artinya:Berikanlah maskawin (mahar) kepada wanita (yang kamu nikahi) sebagai pemberian dengan penuh kerelaan,jika kemudian mereka (wanita) menyerahkan kepada kamu sebagian dari maskawin itu dengan senang hati, maka makanlah (ambillah) sebagai pemberian yang sedap dan baik akibatnya.

Dari keterangan ayat tersebut jelas bahwa suami wajib memberi mahar kepada istrinya sesuai dengan apa yang disampaikan (dijanjikan) pada saat terjadinya akad nikah (mahar musamma) ataupun sejumlah mahar untuk keluarga istri yang tidak ditentukan jumlahnya (mahar mitsil). ${ }^{29}$ Terkait kewajiban bagaimana dan kapan mahar tersebut diberikan, Al-Jashash sebagaimana dalam kutipan Ali al-Sayish menyatakan bahwa mahar hanya wajib diberikan jika telah terjadi hubungan badan.Sementara itu dalam pandangan jumhur, mahar wajib diberikan baik itu setelah adanya hubungan badan ataupun belum. ${ }^{30}$ Artinya, jika terjadi proses perceraian tetap saja mahar wajib diberikan, karena itu merupakan hak istri baik sebelum atau sesudah adanya hubungan badaniyah.

Selain berhak atas mahar sebagaimana ketentuan, istri juga berhak atas nafkaf suami sebagai kebutuhan dan jaminan hidup. ${ }^{31}$ Nafkah secara lebih luas bisa dimaknai sebagai segala sesuatu yang harus diberikan suami kepada istri baik itu berupa kebutuhan material maupun non material serta kebutuhan lainnya termasuk penghargaan atas penyusuan dan pemeliharaan anak. ${ }^{32} \mathrm{Di}$ antara kebutuhan material yang harus diculupi oleh suami misalnya kebutuhan makan, pakaian, tempat tinggal, pelayanan kesehatan dan sebagainya. Sedangkan kebutuhan non material yang merupakan tanggung jawab suami terhadap istri antara lain yaitu:

1) Digauli dengan cara yang baik ( $m a^{\prime} r u f$ ),yaitu bahwa suami dalam melakukan hubungan badaniyah harus mempertimbangkan aspek keadaan dan kondisi istri. Suami tidak boleh memperlakukan istrinya secara kasar dan sewenang-wenang berdasarkan kemauannya sendiri tanpa memperhatikan kebutuhan istri.

2) Menjaga keselamatan, keamanan dan menghindarkan istri dari segala sesuatu yang membahayakan jiwanya, termasuk dari kemungkinan terjerumus ke dalam perbuatan dosa dan maksiat. ${ }^{33}$

\footnotetext{
${ }^{29}$ Kementrian Agama RI, Al-Qur'an dan Tafsirnya: Edisi yang Disempurnakan, Q.S.4:4.

30 Ibid., 182.

31 Ibraahim Muhammad Al-Jamal, fiqih Wanita (Semarang: CV. Asy-Syifa, 1981), 459.

32 Hamim Ilyas, Perempuan Tertindas...., 96.

33 Amir Syarifudin, Hukum Perkawinan di Indonesia antara Fiqh Munakahat dan Undang-Undang Perkawinan, (Jakarta: Kencana, 2006), 161.
} 
3) Mengajarkan dan memahamkan masalah-masalah agama, sehingga istri menjadi pribadi yang taat kepada Allah SWT, baik dalam pergaulan keluarga maupun dalam pergaulan social masyarakat yang lebih luas. ${ }^{34}$

4) Tidak menyakiti jasmani dan rohani istri baik dengan memukul secara langsung atau dengan penghinaan yang menyakiti hatinya.

\section{b. Hak Suami atas Istri}

Kewajiban istri terhadap suami merupakan hak suami yang harus dipenuhi oleh istri, yaitu:

1. Kepatuhan

Seorang suami berhak atas kepatuhan istri, yaitu di mana seorang istri wajib mentaati suaminya, baik terhadap perkara yang rahasia maupun yang terang atau jelas.Seorang istri harus mentaati suaminya karena akan mendatangkan keharmonisan dalam keluarga. Sebaliknya, ketidakpatuhan dan ketidaktaatan istri akan mendatangkan kekecewaan dan keretakan dalam hubungan keluarga. ${ }^{35} \mathrm{Hal}$ ini tidak terlepas bahwa dalam kondisi apapun, suami adalah pemimpin dalam keluarga berdasar pada QS. Al-Nisa': 34 sebagaimana berikut:

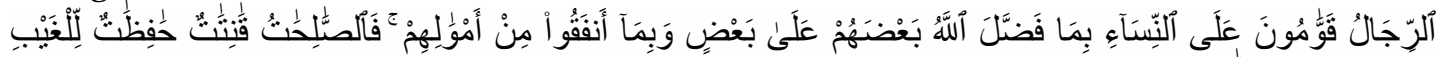

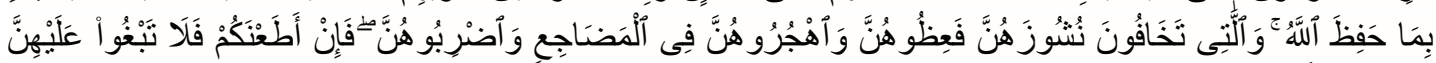

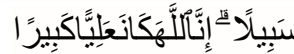
Artinya:Kaum laki-laki itu adalah pemimpin bagi kaum wanita, oleh karena Allah telah melebihkan sebahagian mereka (laki-laki) atas sebahagian yang lain (wanita), dan karena mereka (laki-laki) telah menafkahkan sebagian dari harta mereka. sebab itu Maka wanita yang saleh, ialah yang taat kepada Allah lagi memelihara diri ketika suaminya tidak ada, oleh karena Allah telah memelihara (mereka).

Berdasar ayat tersebut di atas, keharmonisan dalam rumah tangga sangat bergantung pada bagaimana peran dan fungsi suami sebagai pemimpin keluarga melakukan metode kepemimpinannya untuk mengatur keluarganya. Jika kepemimpinan itu buruk maka keharmonisan keluarga akan terancam karena pada saat bersamaan istri yang mestinya patuh dan taat juga akan melakukan perlawanan. Tegasnya, suami wajib menjadi qawwamun yang benarbenar mampu menguasai istri dan keluarganya secara arif dan bijaksana sehingga mendapat kewibaayan, dipatuhi dan ditaati oleh istri beserta segenap anggota keluarga yang lain dalam kondisi apapun juga, baik saat ada di lingkungan keluarga ataupun saat tidak ada (bepergian atau berada di luar rumah). ${ }^{36}$

2. Menjaga diri

34 Abu Malik Kamal Bin Sayyid Salim, Fiqih Sunnah Untuk Wanita (Jakarta:al-I'tishom Cahaya Umat, 2007), 719.

${ }^{35}$ Mustofa Bisri, Bingkisan Pengantin (Sumber Solo: Qaula Smart Media 2008), 142. 
Seorang istri berkewajiban menjaga diri, harta dan keluarganya saat suami tidak sedang berada di rumah. Hal-hal teknis seperti misalnya menerima tamu laki-laki dalam kondisi sendirian mesti dihindari oleh istri karena akan menimbulkan fitnah dan prasangka yang tidak baik. Demikian juga istri tidak boleh sekehendak hatinya memanfaatkan atau membelanjakan harta saat suami sedang tidak ada di rumah, kecuali untuk hal-hal yang mendesak dan setelah mendapat persetujuan suami.Hal-hal ini merupakan hak bagi suami yang tidak bisa dilanggar oleh istri karena menyangkut kewibawaan dan kepribadian seorang laki-laki.

\section{c. Hak Bersama}

Hak bersama suami istri adalah hak yang melekat pada kedua belah pihak yang harus dilakukan dengan penuh kesadaran, tanpa adanya paksaan dan intervensi dari pihak manapun. Menurut Sayyid Sabiq, hak bersama antara suami dan istri meliputi hal-hal sebagaimana berikut, yaitu: ${ }^{37}$

1. Menikmati hubungan seksual. Hubungan seksual yang terjadi antara suami istri adalah merupakan hubungan timbal balik yang harus dilakukan bersama-sama dengan penuh perasaan dan kerelaan atas dasar kasih sayang yang tulus. Salah satu pihak tidak bisa memaksanakan kehendaknya atas yang lain karena hubungan seksual tidak bisa dilakukan secara mandiri oleh salah satu pihak saja.

2. Antara suami dan istri sama-sama dilarang melakukan pernikahan dalam jalur keturunan. Artinya, seorang istri haram dinikahi oleh ayah dari suaminya, kakeknya, anak-anaknya dan cucu-cunya. Demikian juga suami tidak bisa menikasi ibu dari istrinya, anak perempuannya dan cucu-cucunya.

3. Menasabkan anak (keturunan) pada suami yang sah. Baik dalam kondisi masih dalam hubungan suami istri atau setelah perceraian, nasab anak akibat hubungan perkawinan yang sah tetap melekat pada suami (sebagai ayah yang sah).

4. Baik suami ataupun istri wajib memperlakukan pasangannya dengan baik sehingga memunculkan kemesraan antara keduanya. ${ }^{38}$

5. Hak mendapatkan warisan, yaitu bahwa suami ataupun istri berhak mendapatkan warisan jika salah satu dari keduanya meninggal dunia. Baik suami atau istri akan mendapatan hak warisan tanpa penghalang.

37 Fatkhur Rasyid, Babat Sikap-Sikap Istri Terhadap Suami yang Harus Dihindari Sejak Malam Pertama, (Jogjakarta: DIVA Press, 2011), 33.

38 Sayyid Sabiq, Fiqih Sunah Jilid 3: Pengantar Imam Hasan Al-Bana (Jakarta: Pt Nada Cipta Raya, 2004), 39. 


\section{TELAAH RELEVANSI TAFSIR AYAT AHKAM DAN HADITS AHKAM TENTANG HAK DAN KEWAJIBAN SUAMI ISTRI}

\section{Telaah Tentang Kewajiban Suami Yang Menjadi Hak Istri}

Dalam pandangan Asy'ari, ${ }^{39}$ kewajiban suami yang menjadi hak istri adalah memperlakukan istri dengan sebaik-baiknya perlakukan.Suami wajib memberikan mahar, nafkah (biaya hidup), pakaian dan memperlakukan istri dengan tutur kata yang baik, berlaku sabar atas hal-hal tidak baik yang ada pada istri dan menuntunnya ke kalan kebaikan dan ibadah. Seorang suami harus mengajari hal-hal yang dibutuhkan oleh istri seperti tata cara dan hukum bersuci, masalah haid dan juga ibadah fardlu seperti kewajiban shalat dan lain sebagainya.

Dengan hal-hal tersebut di atas, terlihat secara jelas bahwa kewajiban seorang suami terhadap istri, mulai dari keharusan memperlakukan secara baik, memberi hak-hak istri (mahar, nafkah hidup dan sebagainya) hingga kewajiban memberikan pengarahan dan pengajaran dalam urusan dan masalah keagamaan menjadi kesepakatan hampir seluruh ulama'. ${ }^{40}$ Artinya, tidak ada perbedaan mendasar dalam hal kewajiban suami atas istri sebagai hak istri yang harus dipenuhi oleh suami.

Terkait kewajiban suami terhadap istri sebagaimana tersebut di atas, Asy'ari mendasarkannya pada teks al-Hadits sebagaimana berikut: ${ }^{41}$

Ketahuilah, hendaklah kalian melaksanakan wasiatku untuk berbuat baik kepada wanita, karena mereka laksana tawanan yang berada disisi kalian. Kalian tidak berhak atas mereka lebih dari itu, kecuali jika mereka. melakukan perbuatan keji yang nyata. Jika mereka melakukannya, jauhilah mereka di tempat tidur dan pukullah mereka dengan pukulan yang tidak menyakitkan. Jika kemudian mereka menaatimu, maka janganlah kamu mencari-cari jalan untuk menyusahkannya. Ketahuilah; kalian memiliki hak atas istri kalian dan istri kalian memiliki hak atas kalian. Hak kalian atas istri kalian ialah dia tidak diperkenankan membawa orang yang kalian benci ke tempat tidur kalian dan rumah kalian. Ketahuilah; hak istri kalian atas kalian ialah kalian berbuat baik kepada mereka dalam (memberikan) pakaian dan makanan (kepada) mereka.

Lebih jauh tentang kewajiban suami untuk memenuhi hak-hak istri, Asy'ari menekankan pentingnya berbuat baik kepada istri dalam situasi dan kondisi apapun.Suami bisa dan boleh memberi peringatan atas kesalahan yang dilakukan oleh istri tanpa adanya upaya kepura-puraan atau (sekedar) mencari-cari alas an atas kesalahan istri. ${ }^{42}$ Semuanya harus tetap dilakukan oleh suami dalam koridor kebaikan, tanpa kepentingan lain yang disembunyikan. Dalam hal ini Asy'ari memberikan contoh tentang bagaimana berperilaku baik kepada istri walaupun dalam pandangan masyarakan pada saat itu (pada masa hidup Asy'ari) dianggap

39 Hasyim Asy'ari , Da'u al-Misbah fi Bayan Ahkam an-Nikah (Jombang: Pustaka Warisan Islam Tebu Ireng).

40 Ahmad Attabik dan Khoridatul Mudhiiah, "Perkawinan dan Hikmahnya Perspektif Hukum Islam" (Yudisia. Vol. 5, No. 2. Desember.2014).

${ }^{41}$ Hasyim Asy'ari, Da'u al-Misbah fi Bayan Ahkam an-Nikah. Islam".

42 Ahmad Attabik dan Khoridatul Mudhiiah, "Perkawinan dan Hikmahnya Perspektif Hukum 
sebagai sebuah kesia-siaan. Asy'ari (bahkan) kembali menyebut hadits tentang hak istri, yaitu:

"Hak seorang wanita atas suaminya yakni memberi makan kepadanya apabila dia makan, memberi pakaian apabila ia berpakaian, tidak memukulwajah,tidak menjelekjelekkannya dan tidak boleh mendiamkannya kecuali di dalamrumah".

Petikan hadits di atas masih (tetap) berkaitan dengan hadits sebelumnya yang menjelaskan tentang kewajiban suami yang menjadi hak istri. Dari hadits ini kewajiban suami terhadap istri dijelaskan secara detail yaitu berkewajiban memberi makan, pakaian, tidak kasar dan memukul istri dan tidak boleh mendiamkan istri jika ia melakukan kesalahan. Pengajaran dengan mendiamkan istri harus dilakukan secara bijaksana yaitu saat istri berada di rumah, tidak di ruang publik karena hal tersebut akan mempermalukan pribadi istri di muka umum.

Menyempurnakan argumentasinya dalam hal kewajiban suami untuk berbuat baik kepada istri sebagaimana tersebut di atas, Asy'ari juga menyebutkan hadits yang memiliki relevansi sama terhadap pentingnya kewajiban-kewajiban suami tersebut dipenuhi sebagai hak istri secara baik, yaitu al-Hadits yang artinya sebagai berikut, yaitu: ${ }^{43}$

"Sesungguhnya di antara sempurnanya iman seseorang mukmin adalah mereka yang paling baik akhlaknya dan lembut kepadaistrinya"

Dari keterangan-keteragan tersebut di atas, dengan jelas dapat dinyatakan bahwa dalam kehidupannya, Nabi SAW. juga sangat peduli atas hak-hak istri sebagai pemenuhan kewajiban sebagai seorang suami. Seorang suami adalah pemimpin keluarga yang pastinya menginginkan keluarganya bisa hidup secara layak dan terhormat.Karena bukan saja kehadirannya sebagai seorang suami sekaligus sebagai pimpinan keluarga saja.Lebih dari itu juga sebagai seorang ayah yang harus menjadi contoh (tauladan) bagi anak-anaknya.

\section{Telaah Tentang Kewajiban Istri Yang Menjadi Hak Suami}

Sebagaiman kewajiban suami yang harus dilakukan untuk memenuhi hak-hak istri, maka istripun memiliki kewajiban-kewajiban sebagai pemenuhan atas hak-hak suami. Di antara kewajiban-kewajiban istri yang menjadi hak suami itu adalah bahwa istri harus taat kepada suami dalam semua hal yang tidak dilarang agama, melakukan semua perintah suami termasuk tidak boleh berpuasa sunah tanpa izin suami, keluar rumah tanpa izin dan menjauhi semua perkara yang dibenci oleh suami. Secara lebih jelas, hak-hak suami yang menjadi kewajiban istri ini seperti yang diungkapkan oleh Asy'ari dalam kitab Da'u al-Misbah fi Bayan Ahkam anNikahsebagaimana berikut:

"Hak-hak suami yang menjadi kewajiban seorang istri itu banyak, di antaranya seorang istri wajib mentaati suami kecuali dalam hal-hal yang dilarang (agama), istri tidak boleh puasa tanpa izin suami, tidak boleh keluar rumah tanpa izin dan rida suami, istri wajib

${ }^{43}$ Hasyim Asy'ari,...20 
mencari keridaan suami dan berusaha sebisa mungkin menjauhi perkara yang dibenci suaminya".

Berkenaan dengan keterangan di atas, untuk semakin memberikan penegasan tentang pentingnya istri menjalankan kewajibannya untuk taat kepada suaminya, Asy'ari menyatakannya dengan ungkapan sebagaimana berikut, yaitu:44

"Seorang istri harus menyadari bahwa dirinya adalah milik suaminya - ia tidak diperbolehkan menggunakan harta suami kecuali atas izin si suami, suami diperbolehkan berpendapat terkait harta si istri sebab istri merupakan tanggung jawabnya, istriharus memprioritaskan hak-hak suamiatashak-haksaudarasangistri".

Dalam pernyataan tersebut Asy'ari tentang kewajiban istri untuk taat kepada suami terkait pemanfaatan harta. Seorang istri tidak diperbolehkan menggunakan harta suami tanpa izin darinya walaupun itu untuk kepentingan saudarasaudaranya. Kepentingan suami terhadap harta tersebut tetap harus didahulukan karena hal ini termasuk bukti kepatuhan dan juga seberapa besar penghormatan (penghargaa) yang diberikan istri kepada suaminya.Hal ini juga ditegaskan dalam hadits Nabi SAW yang menerankan bahwa seorang istri tidak boleh menggunakan hartanya selama suami tidak mengizinkannya.

"Dari Mujahid, Nabi Saw bersabda: "Seorang istri tidak boleh memakai hartanya jika suaminya menguasainya (tidak memberikan izin)".

Berpijak pada hadits di atas, bahkan jika itu adalah harta istri atau milik pribadinya sekalipun, tetap tidak diperkenankan untuk menggunakannya tanpa izin dari suami.Kondisi ini menggambarkan tentang pentingnya (kewajiban) istri untuk menghormati suami dalam situasi dan kondisi apapun.

Adapun tentang kewajiban istri terhadap suami terkait etika sebagai seorang istri bisa dijabarkan dalam pernyataan Asy'ari sebagai berikut:

"Seorang istri harus menyerahkan diri pada suaminya ketika hendak tidur, menuruti keinginan suaminya (di tempat tidur) dan menjaga harta suaminya, menjaga bau mulutnya agar tetap wangi, selalu berdandan ketika suami ada ataupun sedang bepergian, menghormati keluarga dan kerabat suami, mencari keridhaan suami karena suami adalah surga atau neraka sang istri kelak".

Ketatnya pola hubungan antara suami istri yang mewajibkan istri untuk taat, patuh dan menghormati suami hingga sedemikian rupa sehingga mulai dari tempat tidur, saat terjaga (berdiam dan atau saat menyibukkan diri di dalam rumah) dan saat berada di luar rumah menunjukkan betapa berharga dan urgensinya nilai seorang perempuan (istri) bagi suami dan demikian pula sebaliknya.Hal ini sesuai dengan riwayat hadits dari Aisyah ra.yang berbunyi:

\footnotetext{
${ }^{44}$ Hasyim Asy'ari, 20.
} 
Diriwayatkan dari Aisyah, Aku bertanya kepada Rasulullah Saw, "siapa saja orang yang paling besar memiliki hak atas perempuan? Beliau menjawab "suaminya", aku bertanya lagi "siapa yang paling berhak atas laki-laki? Beliau pun menjawab "ibunya".

Keterangan yang bisa diambil dari hadits tersebut adalah bahwa ada adab-adab tertentu yang memang harus dilakukan oleh istri kepada suaminya, baik itu saat berada di dalam rumah maupun saat di luar rumah.Intinya, seorang istri harus bisa membuat suaminya tersenyum, bahagia dan merasa benar-benar terhormat sebagai seorang laki-laki. Dan hal tersebut hanya akan didapatkan jika seorang istri benarbenar bisa menterjemahkan dan melaksanakan ketentuan-ketentuan yang menjadi kewajibannya sebagai hak suami dengan benar, penuh kesadaran dan rasa cinta terhadap suaminya.

\section{KESIMPULAN}

Berdasarkan hasil pembahasan, dapat diambil kesimpulan: Pertama,relasi antara hak dan kewajiban suami istri dalam rumah tangga menimbulkan hak dan kewajiban yang setara antara keduanya yaitu: hak Istri atas suami, hak suami atas istri, dan hak bersama antara keduanya. Kedua, penafsiran ayat ahkam dengan relevansinya terhadap hadits ahkam tentang hak dan kewajiban suami istri dalam kehidupanrumah tangga dapat dibagi menjadi kewajiban suami yang menjadi hak istri yang dinyatakan dalam alQur'an bahwa suami harus memberi nafkah istri, memperlakukan istri dengan ma'ruf (baik). Hal tersebut selaras dengan tafsir hadits Asy 'ari yang menyatakan bahwa suami mempunyai tanggung jawab penuh atas istri baik dalam nafkah maupun dalam perlakukan sehari-hari. Sedangkan kewajiban istri yang menjadi hak suami adalah bahwa istri wajib menjaga segala sesuatu yang berkenaan dengan milik suami. Hal ini berkesesuaian dengan hadits-haditsyang menyatakan tentang kewajiban istri sebagai hak suami yaitu kewajiban istri meminta izin suami saat berada di dalam rumah, di luar rumah dandalam hal memanfaatkan dan menggunakan harta.

\section{DAFTAR PUSTAKA}

Amin Summa, Muhammad. Hukum Keluarga Islam di Dunia Islam. Jakarta: PT. Raja Grafindo Persada, 2005

Ar-Rifa'i, Muhammad Nasib. Kemudahan dari Allah: Ringkasan Tafsir Ibnu Katsir Jilid 2. Jakarta: Gema Insani.

Bisri, Mustofa. Bingkisan Pengantin. Sumber Solo: Qaula Smart Media, 2008.

Departemen Pendidikan Nasional, Kamus Besar Bahasa Indonesia. Jakarta: Balai Pustaka, 2001.

Hairul Hudaya. “Hadits-Hadits Tentang Penafsiran Hak dan Kewajiban Suami Istri dalam Tafsir At-Tabhari (Studi Kualitas dan Relevansi Kandungannya) Disertasi: UIN Sultan Alaudin Makasar. 2013.

Haris Sanjaya, Umar dan Aunur Rahim Faqih. Hukum Perkawinan Islam di Indonesia. Yogyakarta: Gama Media, 2017.

Hazairin. Undang-Undang Perkawinan No. 1 tahun 1974. Jakarta: Tintamas, 1975. 
Ilyas, Hamim. Perempuan Tertindas; Kajian Hadits-Hadits Misogini. Yogyakarta: EQsaq Pres, Pusat Studi Wanita, UIN Sunan Kalijaga, 2005.

Isnaeni, Moch. Hukum Perkawinan Indonesia. Bandung: PT Refika Aditama, 2016.

https://id.wikipedia.org/wiki/Tafsir. Diakses pada tanggal 14 Oktober 2020 pukul 14.00 WIB.

https://kbbi.web.id/profan. Diakses pada tanggal 13 Oktober 2020 pukul 15.00 WIB.

Jamaa, La. "Advokasi Hak-Hak Istri Dalam Rumah Tangga Perspektif Hukum Islam" (Jurnal, Fakultas Syariah dan Ekonomi Islam IAIN Ambon, 2016).

Kamal Bin Sayyid Salim, Abu Malik. Fiqih Sunnah Untuk Wanita. Jakarta:al-I'tishom Cahaya Umat, 2007.

Kementrian Agama RI, Al-Qur'an dan Tafsirnya: Edisi yang Disempurnakan, Juz 1-3. Jakarta: Widya Cahaya, 2011.

Kementerian Agama RI, Al-Qur'an dan Tafsirnya: Edisi yang Disempurnakan. Jakarta: Widya Cahaya, 2011.

Khoridatul Mudhiiah, Ahmad Attabik "Perkawinan dan Hikmahnya Perspektif Hukum Islam" (Yudisia. Vol. 5, No. 2. Desember. 2014.

Marhumah, "Perempuan Indonesia dalam Memahami hak dan Kewajiban Dalam Keluarga". Jurnal Musawa: Studi Gender dan Islam 2014.

Nawawi bin Umar al-Jawi, Syaikh Muhammad., Keluarga Sakinah, terj. Ali Chasan Umar. Semarang: Karya Toha Putra,1994.

Rasyid, Fatkhur. Babat Sikap-Sikap Istri Terhadap Suami yang Harus Dihindari Sejak Malam Pertama. Jogjakarta: DIVA Press, 2011.

Sabiq, Sayyid. Fiqih Sunah Jilid 3: Pengantar Imam Hasan Al-Bana. Jakarta: Pt Nada Cipta Raya, 2004.

Sabiq, Sayyid. Fiqih Sunah Jilid 3: Pengantar Imam Hasan Al-Bana. Surakarta: Insan Kamil, 2016.

Shihab, M. Quraish. Pengantin Al-Qur'an: Kalung Permata buat Anak-Anakku. Jakarta: Lentera Hati, 2007.

Shihab, M. Quraish. Untaian Permata Buat Anakku: Pesan Al-Qur'an untuk Mempelai. Bandung: Al-Bayan, 1998.

Siti Musdah, Mulia. Membangun Surga Di Bumi; Kiat-Kiat Membina Keluarga Ideal Dalam Islam. Jakarta: PT Gramedia, 2011.

Syarifuddin, Amir. Hukum Perekonomian Islam di Indonesia. Jakarta:Prenada Media, 2006. Amir. Hukum Perkawinan di Indonesia antara Fiqh Munakahat dan UndangUndang Perkawinan. Jakarta: Kencana, 2006.

Wahyu, Wibisana. Perkawinan Dalam Islam. Jurnal Pendidikan Agama Islam -Ta'lim Vol. 14, No. 2. 2016

Witanto, D.W. Hukum Keluarga : Hak dan kedudukan anak luar kawin. Jakarta: Prestasi Pustaka, Jakarta, 2012. 